Brazilian Journal

of Chemical

Engineering

\title{
SIMULTANEOUS LIPID AND CAROTENOID PRODUCTION BY STEPWISE FED-BATCH CULTIVATION OF Rhodotorula mucilaginosa WITH CRUDE GLYCEROL
}

\author{
Renata N. Pereira ${ }^{1}$, Juliane M. da Silveira ${ }^{1}$, Janaína F. de M. Burkert ${ }^{1}$, \\ Joana da C. Ores ${ }^{1}$ and Carlos A. V. Burkert ${ }^{1 *}$ \\ ${ }^{1}$ Universidade Federal do Rio Grande, Escola de Química e Alimentos, Rio Grande, RS, Brasil. ORCID 0000-0001-8658-3937; \\ ORCID: 0000-0002-8599-4838; ORCID: 0000-0002-8504-5376; ORCID: 0000-0002-1156-1028; E-mail: burkert@furg.br - \\ ORCID: 0000-0003-0169-0894
}

(Submitted: April 17, 2019 ; Revised: June 25, 2019 ; Accepted: July 5, 2019)

\begin{abstract}
In the present study, an innovative cultivation strategy of Rhodotorula mucilaginosa CCT 7688 to accumulate both lipids and high added value carotenoids was proposed, with the potential to contribute to the economic feasibility of microbial oils in comparison with vegetable oils. The stepwise fed-batch cultivation with crude glycerol feeding at $24 \mathrm{~h}, 96 \mathrm{~h}$, and $144 \mathrm{~h}$, with the addition of magnesium to the initial culture medium, resulted in a lipid content of $51.0 \pm 0.3 \% \mathrm{CDW}$, biomass concentration of $21.00 \pm 0.48 \mathrm{~g} \mathrm{~L}^{-1}$, total lipid production of $10.72 \pm 0.18 \mathrm{~g} \mathrm{~L}^{-1}$, lipid productivity of $0.037 \pm 0.001 \mathrm{~g} \mathrm{~L}^{-1} \mathrm{~h}^{-1}$, volumetric carotenoid production of $2843.2 \pm 282.0 \mu \mathrm{g} \mathrm{L}^{-1}$, and carotenoid productivity of $9.87 \pm 0.98 \mu \mathrm{g} \mathrm{L}^{-1} \mathrm{~h}^{-1}$. These values represent a 6-fold increase in lipid content, a 19-fold increase in lipid production, and a 2 -fold increase in carotenoid production compared to batch cultivation.
\end{abstract}

Keywords: Feeding strategies; Oleaginous yeasts; Microbial lipids; $\beta$-carotene.

\section{INTRODUCTION}

Lipids have broad potential applications in various industrial sectors and can be used in food, food supplementation, oleochemicals, and biofuel production, including biodiesel. The growing biodiesel production is essentially dependent on vegetable oils, which has led to many discussions regarding the competition with food and feed production (Koizumi, 2015; Koutinas et al., 2014).

In this context, alternative raw materials have been investigated, with several studies on the production of microbial lipids (Angerbauer et al., 2008; Béligon et al., 2015; Chang et al., 2013; Chen et al., 2013; Zhao et al., 2008). Oleaginous yeasts stand out among the lipid-producing microorganisms due to their high growth rate and ability to assimilate a wide variety of carbon sources (Moliné et al., 2012), such as crude glycerol from biodiesel production.

Glycerol is the main byproduct of biodiesel production and approximately $10 \%$ of the weight of biodiesel is generated in glycerol (Quispe et al., 2013). With the growing demand for biodiesel, this byproduct is increasingly easy to obtain, reducing its commercial value. According to the UFOP report for 2017/2018, world biodiesel production amounted to 34.08 million tonnes in 2016. The most important biodiesel producer was the European Union (12.61 million tonnes), followed by the United States (6.21 million tonnes) and Brazil (3.30 million tonnes). Therefore, solutions are required regarding the use of the crude glycerol generated in this production.

Different oleaginous yeasts have demonstrated an ability to synthesize lipids using the crude glycerol

\footnotetext{
* Corresponding author: Carlos A. V. Burkert - E-mail: burkert@furg.br
} 
derived from biodiesel production as a carbon source (Liang et al., 2010; Saenge et al., 2011; Thiru et al., 2011; Duarte et al., 2013). The use of this byproduct to obtain microbial oil may be a promising alternative, since it can add value to the biodiesel production chain, thus making it more competitive (Silva et al., 2009). However, microbial oils (mainly from yeasts) are not a viable alternative for both biodiesel production and other processes in the substitution of vegetable oils, mainly due to the cultivation costs (e.g. aeration, agitation, and sterilization) (Koutinas et al., 2014; Tchakouteu et al., 2017).

The yeast Rhodotorula mucilaginosa has shown a great potential for lipid production and, as a red yeast, has the capacity to synthesize carotenoids, a high valueadded bioproduct that, if produced simultaneously, can make the process economically viable. Carotenoids are natural pigments widely used in the food, pharmaceutical, cosmetic, and animal feed industries due to their biological properties, such as antioxidant activity (Valduga et al., 2009). Greater consumer awareness with regard to health and functional foods has triggered an increase in the demand for carotenoids, highlighting the biotechnological production due to the proven biological activity of these biomolecules (Cipolatti et al., 2015).

Thus, the conditions that favor cell growth and lipid and carotenoid accumulation should be investigated, including the cultivation mode. In the stepwise fedbatch process, feeding is intermittent and allows the regulation of the feeding of the substrate, preventing an inhibitory activity in biomass growth and lipid accumulation (Shuler and Kargi, 2012). Furthermore, some authors found an increase in lipid production in the fed-batch process compared with the batch process (Fei et al., 2016; Saenge et al., 2011). This cultivation strategy may be a promising alternative, attracting the attention of several researchers regarding the production of microbial oils by this process (Anschau et al., 2014; Béligon et al., 2015; Cescut et al., 2014; Chang et al., 2013; Fei et al., 2016; Pirozzi et al., 2014; Raimondi et al., 2014; Rakicka et al., 2015). However, studies that involve the simultaneous lipid and carotenoid production by fed-batch processes remain scarce.

Therefore, the main goal of this study was to evaluate different stepwise fed-batch cultivation strategies for the yeast $R$. mucilaginosa CCT 7688 in crude glycerol-based medium and the effects on biomass concentration, lipid production, and carotenoid production.

\section{MATERIAL AND METHODS}

\section{Yeast strain}

The yeast Rhodotorula mucilaginosa CCT 7688 (André Tosello Foundation, Campinas, Brazil) was previously isolated and identified by our research group, and characterized by PCR fingerprinting, i.e., the mini/microsatellite-primed PCR technique (MSPPCR), in accordance with Libkind et al. (2003).

The strain was reactivated by transferring it to Yeast Malt (YM) agar slants, composed of $\left(\mathrm{g} \mathrm{L}^{-1}\right)$ : 10 glucose, 5 peptone, 3 malt extract, 3 yeast extract, and 20 agar. The tubes were incubated at $25^{\circ} \mathrm{C}$ for $48 \mathrm{~h}$ (Spier et al., 2015).

\section{Crude glycerol}

The crude glycerol was purchased from BS Bios Indústria e Comércio de Biodiesel Sul Brasil S/A, located in Passo Fundo (Brazil), obtained from the biodiesel production of degummed soybean oil by the methanolic route. The crude glycerol contained (\%): 81.92 glycerol (Official monographs USP XXI, 1985), 11.29 moisture (AOCS, 2004), 5.38 ashes (Official monographs USP XXI, 1985), and 1.41 nonglyceridic organic matter (by difference), pH 5.39.

\section{Pre-inoculum and inoculum preparation}

To prepare the pre-inoculum, two tubes of the reactivated microbial culture were scraped with $10 \mathrm{~mL}$ of $0.1 \%$ peptone diluent to each tube for the removal of the microorganism cells and transferred to an Erlenmeyer flask containing $180 \mathrm{~mL}$ of YM broth. The culture medium was prepared in concentrated form to attain the desired composition after inoculation (10 $\mathrm{g} \mathrm{L}^{-1}$ of glucose, $5 \mathrm{~g} \mathrm{~L}^{-1}$ of peptone, $3 \mathrm{~g} \mathrm{~L}^{-1}$ of malt extract and $3 \mathrm{~g} \mathrm{~L}^{-1}$ of yeast extract) and incubated in a rotary shaker (Tecnal TE-424, Brazil) at $25^{\circ} \mathrm{C}$ and 180 rpm (Spier et al., 2015). After 48 h, $20 \mathrm{~mL}$ of the preinoculum were transferred to the inoculum medium $(180 \mathrm{~mL})$ with the same composition and incubated under the same temperature and stirring conditions. After $72 \mathrm{~h}$, the number of cells was counted in a Neubauer chamber $\left(10^{8}\right.$ cells $\left.\mathrm{mL}^{-1}\right)$.

\section{Batch cultivation}

The batch cultivation was carried out in $500 \mathrm{~mL}$ Erlenmeyer flasks with an initial volume of $200 \mathrm{~mL}$, using a rotary shaker (Tecnal TE-424, Brazil) at 180 $\mathrm{rpm}$ and $25^{\circ} \mathrm{C}$. The inoculum corresponded to $10 \%$ of the initial volume and the total cultivation time was $168 \mathrm{~h}$. The composition of the medium (YMG) was adapted from the YM broth, replacing the glucose with crude glycerol, maintaining the same $\mathrm{C} / \mathrm{N}$ ratio (7.63). The concentrations of the components were established using Excel software (Solver tool) (Microsoft Inc., USA), considering this $\mathrm{C} / \mathrm{N}$ ratio and the composition of the components in terms of carbon and nitrogen contents, determined in a $\mathrm{CHNS} / \mathrm{O}$ Elemental Analyzer (Model 2400 Series II, Perkin Elmer, USA), using acetanilide as a reference (Table $1)$. The medium composition was $\left(\mathrm{g} \mathrm{L}^{-1}\right)$ : 10.4 crude glycerol, 4.3 peptone, 2.6 malt extract, and 3.4 yeast extract, without $\mathrm{pH}$ adjustment. 
Table 1. Carbon, nitrogen and hydrogen content of the culture medium components.

\begin{tabular}{cccc}
\hline Component & \% C & \% H & \% N \\
\hline Peptone & 43.47 & 6.32 & 15.32 \\
Yeast extract & 39.12 & 6.23 & 10.66 \\
Crude glycerol & 31.50 & 2.27 & $<0.07$ \\
Malt extract & 40.47 & 5.25 & 1.22 \\
\hline
\end{tabular}

\section{Stepwise fed-batch cultivation}

First, the cultivation conditions and the medium composition were the same in the batch mode, and the microbial growth curve was used as the basis for establishing the fed-batch cultivation strategies. The first two strategies (YMG24 and YMG96) consisted of feeding $20 \mathrm{~mL}$ of aqueous solution $(10 \%$ initial volume), containing only crude glycerol $\left(104 \mathrm{~g} \mathrm{~L}^{-1}\right)$, at different feeding times: a pulse in the exponential phase $(24 \mathrm{~h})$ or the stationary phase $(96 \mathrm{~h})$. New strategies were then proposed (Table 2), increasing the number of feedings (YMG1, YMG2 and YMG3). Cultivations with the addition of $3 \mathrm{~g} \mathrm{~L}^{-1}$ magnesium sulfate and/or $\mathrm{pH}$ adjustment of the culture medium to 4.5 were also performed (YMG4, YMG5 and YMG6).

\section{Analytical methods}

During the cultivation, samples were taken at regular intervals to determine the biomass concentration, glycerol concentration, and $\mathrm{pH}$. The lipids and carotenoids in the recovered biomass were determined at the end of the process.

\section{Biomass}

Samples were centrifuged (Eppendorf 5804 R, Germany) at $10414 \times \mathrm{g}$ for $15 \mathrm{~min}$, and the cells (pellet) were washed with distilled water, centrifuged again and resuspended. The optical density was then measured in a spectrophotometer (Bioespectro SP 220 , China) at $600 \mathrm{~nm}$. Using a previously established standard curve for the microorganism, the biomass concentration in cell dry weight $\left(\mathrm{g} \mathrm{L}^{-1}\right)$ was determined for each sample (Choi and Park, 2003).

\section{pH}

The $\mathrm{pH}$ of the supernatant was measured with a $\mathrm{pH}$ meter, in accordance with AOAC (2000).

\section{Glycerol}

The glycerol in the supernatant was determined by the method described by Bondioli and Bella (2005), based on the reaction with sodium periodate, with an absorbance reading at $410 \mathrm{~nm}$. The absorbance values were converted to glycerol concentration $\left(\mathrm{g} \mathrm{L}^{-1}\right)$ using a predetermined standard curve (Equation 1).

Glycerol concentration $\left(\mathrm{g} \mathrm{L}^{-1}\right)=0.0996 \times$ Absorbance

\section{Lipid content}

The lipid content, expressed as a percentage of cell dry weight (\% CDW), was determined in the dry biomass (300-500 mg) using the method of Bligh and Dyer (1959), adapted by Manirakiza et al. (2001). The dry biomass was obtained through the centrifugation $(10414 \times \mathrm{g}$ for $15 \mathrm{~min})$ of the remaining medium at the end of the cultivation, washing with distilled water, centrifugation again, drying at $35^{\circ} \mathrm{C}$ (Michelon et al., 2012) until constant weight and crushing to powder in a mortar and pestle. Total lipid production $\left(\mathrm{g} \mathrm{L}^{-1}\right)$ was calculated by multiplying the biomass concentration by the lipid content (Spier et al., 2015). Lipid productivity $\left(\mathrm{g} \mathrm{L}^{-1} \mathrm{~h}^{-1}\right)$ was calculated by dividing total lipid production by time.

\section{Fatty acid profile}

To determine the fatty acid profile, the lipid fraction was esterified to obtain fatty acid methyl esters (Metcalfe et al., 1966). The samples were then analyzed using a gas chromatograph (Shimadzu 2010 Plus, Japan), equipped with a split/splitless injector, a Rtx ${ }^{\circledR}-1$ capillary column $(30 \mathrm{~m} \times 0.25$ $\mathrm{mm}$ internal diameter $\times 0.25 \mu \mathrm{m}$ particle diameter) and a flame ionization detector. Hydrogen was used as the carrier gas at a flow rate of $1.25 \mathrm{~mL} \mathrm{~min}^{-1}$, and the injector and detector temperatures were $260^{\circ} \mathrm{C}$. The initial column temperature was $50{ }^{\circ} \mathrm{C}$, rising to $200{ }^{\circ} \mathrm{C}$ at a rate of $6{ }^{\circ} \mathrm{C} \mathrm{min}^{-1}$, remaining $4 \mathrm{~min}$ at this temperature. This was followed by a further increase of $2{ }^{\circ} \mathrm{C} \mathrm{min}^{-1}$, until the temperature reached $240{ }^{\circ} \mathrm{C}$, at which it remained for $10 \mathrm{~min}$. SigmaAldrich standards were used to identify the fatty acids, which were quantified by area normalization (Massarolo et al., 2016).

Table 2. Strategies for stepwise fed-batch cultivations.

\begin{tabular}{cccc}
\hline Assay & Feeding times $(\mathbf{h})$ & Pulse feeding $(\mathbf{m L})$ & Other conditions \\
\hline YMG24 & 24 & 20 & - \\
YMG96 & 96 & 20 & - \\
YMG1 & $24 / 96$ & $20 / 20$ & - \\
YMG2 & $24 / 96 / 144$ & $20 / 20 / 20$ & - \\
YMG3 & $24 / 72 / 120$ & $20 / 20 / 20$ & Initial pH at 4.5 \\
YMG4 & $24 / 96 / 144$ & $20 / 20 / 20$ & Addition of $\mathrm{MgSO}_{4} .7 \mathrm{H}_{2} \mathrm{O}$ \\
YMG5 & $24 / 96 / 144$ & $20 / 20 / 20$ & Addition of $\mathrm{MgSO}_{4} .7 \mathrm{H}_{2} \mathrm{O}$ and initial $\mathrm{pH}$ at 4.5 \\
YMG6 & $24 / 96 / 144$ & $20 / 20 / 20$ &
\end{tabular}




\section{Carotenoid concentration}

The total carotenoids (TC) were determined according to the methodology of Fonseca et al. (2011), modified by Cipolatti et al. (2015). For this purpose, $2 \mathrm{~mL}$ of dimethylsulfoxide $\left(55^{\circ} \mathrm{C}\right)$ was mixed with $0.05 \mathrm{~g}$ dry biomass $\left(35^{\circ} \mathrm{C}\right.$ for $48 \mathrm{~h}$ ), ground, sieved (Tyler 115$)$ and frozen $\left(-18{ }^{\circ} \mathrm{C}\right.$ for 48 h). The suspension was stirred for $1 \mathrm{~min}$ at $15 \mathrm{~min}$ intervals, totaling $1 \mathrm{~h}$. Afterwards, $6 \mathrm{~mL}$ acetone was added, and the sample was centrifuged (1745 x $\mathrm{g}$ for $10 \mathrm{~min}$ ) to remove the solvent. The procedure was repeated until the cells were colorless. Following this, $10 \mathrm{~mL}$ of $20 \% \mathrm{w} / \mathrm{v} \mathrm{NaCl}$ and $10 \mathrm{~mL}$ petroleum ether were added to the solvent extract. After stirring and phase separation, the excess water was removed with sodium sulfate (Michelon et al., 2012). The absorbance was then measured in a spectrophotometer at $448 \mathrm{~nm}$ (Machado and Burkert, 2015) and the total carotenoids were calculated using Equation 2, as reported by Davies (1976).

$\mathrm{TC}=\frac{\mathrm{A} \times \mathrm{V} \times 10^{6}}{\mathrm{~A}_{1 \mathrm{~cm}}^{1 \%} \times 100 \times \mathrm{W}}$

where TC is the total carotenoid concentration $\left(\mu \mathrm{g} \mathrm{g}^{-1}\right)$, $\mathrm{A}$ is the absorbance, $\mathrm{V}$ is the volume of carotenogenic extract $(\mathrm{mL}), \mathrm{A}_{1 \mathrm{~cm}}{ }^{1 \%}$ is the specific absorptivity, and $\mathrm{W}$ is the cell dry weight $(\mathrm{g})$.

To calculate the volumetric concentration of carotenoids $\left(\mu \mathrm{g} \mathrm{L}^{-1}\right)$, the $\mathrm{TC}$ was multiplied by the biomass concentration (cell dry weight) (Machado and Burkert, 2015).

\section{Statistical analysis}

The experiments were conducted in triplicate, using ANOVA followed by Tukey's test to verify significant differences between the cultivation conditions at a $95 \%$ confidence level ( $\mathrm{p} \leq 0.05)$, using Statistica 5.0 software (Stat Soft Inc., USA).

\section{RESULTS AND DISCUSSION}

\section{Batch and stepwise fed-batch cultivation with YMG medium}

As shown in Table 3, no significant lipid accumulation was observed in $R$. mucilaginosa CCT 7688 for the batch cultivation (lipid content of 8.5 $\% \mathrm{CDW}$ and total lipid production of $0.57 \mathrm{~g} \mathrm{~L}^{-1}$ ), probably due to the $\mathrm{C} / \mathrm{N}$ ratio used (7.63), with no nitrogen limitation. Nitrogen limitation is generally the most efficient type of regulation for inducing lipid accumulation, since the carbon is distributed among the different macromolecular groups (carbohydrates, lipids, nucleic acids, and proteins) during the microbial growth phase, and nitrogen is essential for the synthesis of nucleic acids and proteins, which are required for cell growth. With nitrogen limitation, the growth rate decreases rapidly, while the carbon assimilation rate decreases more gradually. Thus, the carbon flux is channeled into the lipid synthesis, allowing the accumulation of triacylglycerols (Beopoulos et al., 2009).

Angerbauer et al. (2008) studied the yeast Lipomyces starkeyi using glucose as carbon source and observed an increase in lipid content from $34 \%$ CDW to $68 \% \mathrm{CDW}$, and total lipid production from 4.1 to $6.4 \mathrm{~g} \mathrm{~L}^{-1}$ when the $\mathrm{C} / \mathrm{N}$ ratio changed from 15 to 150 .

Based on the growth curve of $R$. mucilaginosa CCT 7688 in batch cultivation (Figure 1), strategies YMG24 and YMG96 were established (Table 2), i.e., crude glycerol feeding within $24 \mathrm{~h}$ or $96 \mathrm{~h}$, respectively. It is important to note that all stepwise fed-batch cultivations began with the same medium used in batch cultivation in order to provide initially a $\mathrm{C} / \mathrm{N}$ ratio that promotes microbial growth, followed by crude glycerol feedings at specific time intervals that provide an excess of carbon and an increase in

Table 3. Comparison of lipid production between the batch and stepwise fed-batch process.

\begin{tabular}{cccccc}
\hline Assay & $\begin{array}{c}\text { Lipid content } \\
(\mathbf{\%} \text { CDW) }\end{array}$ & $\begin{array}{c}\text { Biomass } \\
\left(\mathbf{g ~ L}^{-\mathbf{1}}\right)\end{array}$ & $\begin{array}{c}\text { Total lipid } \\
\left(\mathbf{g ~ L ~}^{-1}\right)\end{array}$ & $\begin{array}{c}\text { Lipid productivity } \\
\left(\mathbf{g ~ L}^{-1} \mathbf{h}^{-1}\right)\end{array}$ & $\begin{array}{c}\text { Total time } \\
\text { of cultivation }\end{array}$ \\
\hline Batch & $8.5^{\mathrm{e}} \pm 0.5$ & $6.77^{\mathrm{c}} \pm 0.76$ & $0.57^{\mathrm{e}} \pm 0.09$ & $0.003^{\mathrm{e}} \pm 0.001$ & 168 \\
YMG24 & $9.5^{\mathrm{e}} \pm 1.9$ & $14.47^{\mathrm{b}} \pm 1.52$ & $1.38^{\mathrm{d}, \mathrm{e}} \pm 0.27$ & $0.008^{\mathrm{d}, \mathrm{e}} \pm 0.002$ & 168 \\
YMG96 & $9.1^{\mathrm{e}} \pm 0.5$ & $13.22^{\mathrm{b}} \pm 1.87$ & $1.21^{\mathrm{d}, \mathrm{e}} \pm 0.24$ & $0.007^{\mathrm{c}, \mathrm{d}, \mathrm{e}} \pm 0.001$ & 168 \\
YMG1 & $16.0^{\mathrm{d}} \pm 1.3$ & $14.54^{\mathrm{b}} \pm 2.28$ & $2.35^{\mathrm{c}, \mathrm{d}} \pm 0.55$ & $0.014^{\mathrm{c}} \pm 0.003$ & 168 \\
YMG2 & $21.4^{\mathrm{c}} \pm 1.5$ & $14.23^{\mathrm{b}} \pm 2.35$ & $3.04^{\mathrm{c}} \pm 0.39$ & $0.013^{\mathrm{c}, \mathrm{d}} \pm 0.002$ & 240 \\
YMG3 & $15.9^{\mathrm{d}} \pm 4.1$ & $17.57^{\mathrm{a}, \mathrm{b}} \pm 0.99$ & $2.78^{\mathrm{c}} \pm 0.70$ & $0.012^{\mathrm{c}, \mathrm{d}} \pm 0.003$ & 240 \\
YMG4 & $44.3^{\mathrm{b}} \pm 1.3$ & $17.61^{\mathrm{a}, \mathrm{b}} \pm 0.54$ & $7.81^{\mathrm{b}} \pm 0.47$ & $0.027^{\mathrm{b}} \pm 0.002$ & 288 \\
YMG5 & $51.0^{\mathrm{a}} \pm 0.3$ & $21.00^{\mathrm{a}} \pm 0.48$ & $10.72^{\mathrm{a}} \pm 0.18$ & $0.037^{\mathrm{a}} \pm 0.001$ & 288 \\
YMG6 & $50.9^{\mathrm{a}} \pm 1.2$ & $17.08^{\mathrm{a}, \mathrm{b}} \pm 1.02$ & $8.68^{\mathrm{b}} \pm 0.47$ & $0.030^{\mathrm{b}} \pm 0.002$ & 288 \\
\hline
\end{tabular}

Mean values \pm standard deviation, $\mathrm{n}=3$.

Different letters in the same column indicate a significant difference at $95 \%$ confidence level $(\mathrm{p}<0.05)$.

YMG24: $20 \mathrm{~mL}$ crude glycerol within $24 \mathrm{~h}$; YMG96: $20 \mathrm{~mL}$ crude glycerol within $96 \mathrm{~h}$; YMG1: $20 \mathrm{~mL}$ crude glycerol within $24 \mathrm{~h}$, and $20 \mathrm{~mL}$ within 96 h; YMG2: $20 \mathrm{~mL}$ crude glycerol within $24 \mathrm{~h}, 20 \mathrm{~mL}$ within $96 \mathrm{~h}$, and $20 \mathrm{~mL}$ within $144 \mathrm{~h}$. YMG3: $20 \mathrm{~mL}$ crude glycerol within $24 \mathrm{~h}, 20 \mathrm{~mL}$ within $72 \mathrm{~h}$, and $20 \mathrm{~mL}$ within $120 \mathrm{~h}$; YMG4: $20 \mathrm{~mL}$ crude glycerol within $24 \mathrm{~h}, 20 \mathrm{~mL}$ within $96 \mathrm{~h}$, and $20 \mathrm{~mL}$ within $144 \mathrm{~h}$, with initial pH adjustment at 4.5 ; YMG5: $20 \mathrm{~mL}$ crude glycerol within $24 \mathrm{~h}, 20 \mathrm{~mL}$ within $96 \mathrm{~h}$, and $20 \mathrm{~mL}$ within $144 \mathrm{~h}$, with the addition of $3 \mathrm{~g} \mathrm{~L}^{-1} \mathrm{MgSO}_{4} .7 \mathrm{H}_{2} \mathrm{O}_{\text {to }}$ the initial medium; YMG6: $20 \mathrm{~mL}$ crude glycerol within $24 \mathrm{~h}, 20 \mathrm{~mL}$ within $96 \mathrm{~h}$, and $20 \mathrm{~mL}$ within $144 \mathrm{~h}$, with pH adjustment at 4.5 , and the addition of $3 \mathrm{~g} \mathrm{~L}^{-1} \mathrm{MgSO}_{4} .7 \mathrm{H}_{2} \mathrm{O}$ to the initial medium. 


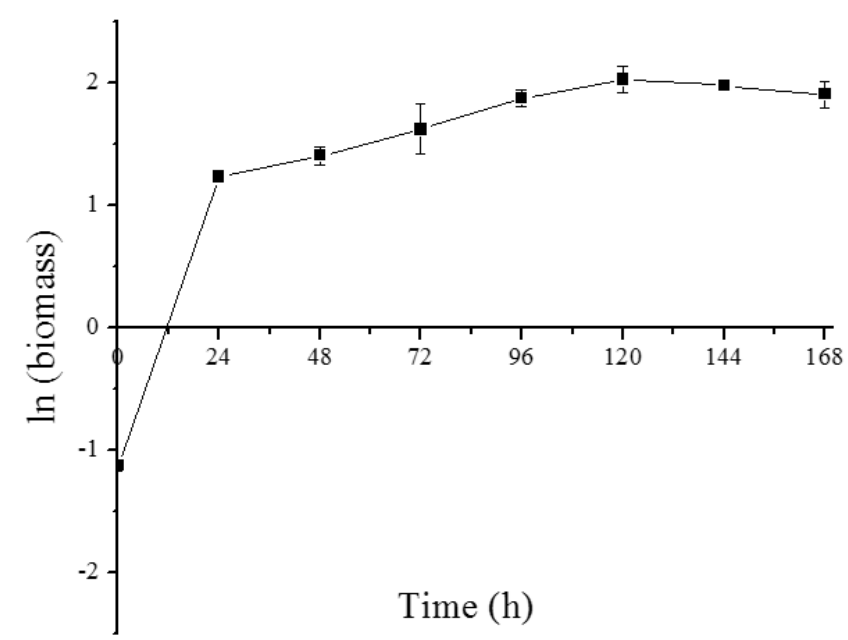

Figure 1. Growth curve of the microorganism in batch cultivation. Mean values \pm standard deviation $(n=3)$.

$\mathrm{C} / \mathrm{N}$ ratio that promotes lipid accumulation, because a high total lipid production depends on both biomass and lipid content. Therefore, this cultivation strategy seeks to reconcile both high biomass and lipid content to improve lipid production.

According to Table 3, an increase in biomass concentration was observed (from 6.77 to 14.47 and $13.22 \mathrm{~g} \mathrm{~L}^{-1}$, respectively), probably due to the greater availability of the carbon source and the presence of nitrogen. However, there was no change in lipid content, with no significant differences between these two strategies.

In contrast, when more than one feeding with crude glycerol was used (YMG1, YMG2, and YMG3), the lipid synthesis capacity also increased, probably due to the significant amount of carbon introduced into the medium, resulting in an increase in the $\mathrm{C} / \mathrm{N}$ ratio, favoring the lipid accumulation in the cells. One of the differences among the strategies YMG1, YMG2, and YMG3 was the feeding time (Table 2). Moreover, YMG2 and YMG3 exhibited one more feeding compared to YMG1 (Table 2). This higher carbon availability, together with the feeding time, allowed a greater lipid accumulation in YMG2. Compared with the batch process, the total lipid production increased by more than $400 \%$ in this condition. Saenge et al. (2011) compared the results from batch and fed-batch processes for the yeast $R$. glutinis TISTR 5159, and reported that the fed-batch led to an increase of approximately $41 \%$ in total lipid production (from $4.33 \mathrm{~g} \mathrm{~L}^{-1}$ to $6.10 \mathrm{~g} \mathrm{~L}^{-1}$ ). Thus, the lipid productivity also increased from $0.058 \mathrm{~g}$ $\mathrm{L}^{-1} \mathrm{~h}^{-1}$ to $0.085 \mathrm{~g} \mathrm{~L}^{-1} \mathrm{~h}^{-1}$. Fei et al. (2016) compared the batch and the fed-batch processes and observed that the latter provided an increase in productivity from $0.28 \mathrm{~g}$ $\mathrm{L}^{-1} \mathrm{~h}^{-1}$ to $0.40 \mathrm{~g} \mathrm{~L}^{-1} \mathrm{~h}^{-1}$.

No significant differences were observed in the biomass concentration when YMG24 and YMG96 are compared with both YMG1 and YMG2 (Table 3), despite the addition of increasing quantities of glycerol. During the growth phase, yeast metabolism results in the balanced distribution of carbon between the four main macromolecules (carbohydrate, lipid, nucleic acid and protein). In conditions of nitrogen limitation (increase in the $\mathrm{C} / \mathrm{N}$ ratio), caused by an excess of glycerol feeding, nucleic acid and protein synthesis are repressed and the growth rate slows down (Beopoulos et al., 2009).

The different times of cultivation for the different strategies are also shown in Table 3 . The respective times were established according to stationary phase achievement, where lipid accumulation increases. This fact is associated with the different strategies used because the glycerol feedings lead to a higher substrate availability that impacts cell growth and extends the exponential phase. The oleaginous yeasts tend to accumulate lipids in the stationary phase, when the nitrogen present in the medium is already exhausted, channeling the carbon flow to the lipid synthesis instead of the growth, allowing the accumulation of triacylglycerols. Comparing the YMG1 and YMG2 strategies, an increase in time (from $168 \mathrm{~h}$ to $240 \mathrm{~h}$, respectively) was observed, since the YMG2 strategy presents three feedings instead of two, increasing the quantity of glycerol in the medium, which provided an extension in the consumption of this carbon source. The same occurred for the assays YMG4, YMG5 and YMG6, which presented longer cultivation times when compared with the strategies with one or two feeds.

\section{Effect of initial pH adjustment}

During the first cultivation with no $\mathrm{pH}$ adjustment, an expressive increase in $\mathrm{pH}$ was observed, reaching pH 8 (data not shown). These values were above those recommended in the literature for microbial growth, since the most frequently reported $\mathrm{pH}$ values ranged from 3 and 6 (Ageitos et al., 2011). This behavior indicated the need to evaluate the influence of the initial $\mathrm{pH}$ on the performance of the microorganism. Therefore, an assay with adjustment of the initial $\mathrm{pH}$ to 4.5 was proposed (YMG4).

The cultivation YMG4 led to an increase in lipid content from $21.4 \% \mathrm{CDW}$ to $44.3 \% \mathrm{CDW}$ and total lipids from $3.04 \mathrm{~g} \mathrm{~L}^{-1}$ to $7.81 \mathrm{~g} \mathrm{~L}^{-1}$ compared with the YMG2 subjected to the same feeding, without adjustment of the initial $\mathrm{pH}$. The final $\mathrm{pH}$ of the cultivation YMG4 was 4.32. Similar behavior was observed by other authors. Karatay and Dönmez (2010) found an increase in lipid content from 31.5\% CDW to $59.9 \%$ CDW for Candida lipolytica with an increase in $\mathrm{pH}$ of the medium from 4 to 5 . Angerbauer et al. (2008) evaluated the effect of $\mathrm{pH}$ on the cultivation of Lipomyces starkeyi and found a lipid content of approximately $7 \% \mathrm{CDW}$ at $\mathrm{pH} 7.0$ and approximately $56 \% \mathrm{CDW}$ at $\mathrm{pH} 5$. 


\section{Effect of the addition of magnesium}

As reported by Taha et al. (2013), the addition of magnesium to the medium favors the lipid accumulation in the microorganism. Based on previous studies (data not shown), assays have been proposed with the addition of magnesium sulfate to the initial culture medium (YMG5, YMG6, with and without $\mathrm{pH}$ adjustment, respectively). YMG5 resulted in lipid content of $51.0 \% \mathrm{CDW}$, biomass concentration of $21.00 \mathrm{~g} \mathrm{~L}^{-1}$, total lipid production of $10.72 \mathrm{~g} \mathrm{~L}^{-1}$, and lipid productivity of $0.037 \mathrm{~g} \mathrm{~L}^{-1} \mathrm{~h}^{-1}$, with significant differences from the other conditions tested in relation to total lipid production and lipid productivity (Table 3). Compared with the batch process (Table 3 ), this strategy represented an increase in lipid accumulation and biomass production of approximately $500 \%$ and $200 \%$, respectively, and an increase in lipid productivity and lipid production of approximately 12 and 19 times, respectively.

The kinetic profile of both cultivations is shown in Figure 2. In the batch cultivation, the $\mathrm{pH}$ remained close to 8.0 , a value considered above that recommended in the literature for the growth of microorganisms. For YMG5 cultivation, after an increase to 8 , the $\mathrm{pH}$ values decreased to 6 due to stepwise feedings that favored lipid accumulation. A decrease in $\mathrm{pH}$ is expected because lipid accumulation is followed by citric acid production, leading to a $\mathrm{pH}$ reduction (Beopoulos et al., 2009). In relation to the glycerol consumption in the YMG strategy, after each feeding time, glycerol concentration almost doubled in relation to the amount present in the culture medium, and was then quickly consumed by the yeast, whereas in the batch strategy, almost all of the glycerol was consumed.

When compared, YMG2 and YMG5, which differ only with regard to the addition of magnesium, an increase in lipid content and lipid production was observed, with values ranging from $21.4 \% \mathrm{CDW}$ to $51.0 \% \mathrm{CDW}$ and $3.04 \mathrm{~g} \mathrm{~L}^{-1}$ to $10.72 \mathrm{~g} \mathrm{~L}^{-1}$, respectively. This higher lipid accumulation in the presence of magnesium sulfate may be due to the action of $\mathrm{Mg}^{2+}$ on the cellular metabolism during the lipid biosynthesis.

According to Beopoulos et al. (2009), the triacylglycerol synthesis occurs from the Kennedy pathway and monoacylglycerol, in which glycerol-3phosphate is acylated to lysophosphatidic acid (LPA) by the enzyme glycerol-3-phosphate acyltransferase (SCT1), which generates phosphatidic acid (PA) after acylation by the enzyme lysophosphatidic acid acyltransferase (SLC1). It undergoes dephosphorylation by the enzyme phosphatidic acid phosphohydrolase (PAP), becoming diacylglycerol (DAG), which leads to the formation of triacylglycerol (TAG) after the acyl-CoA reaction, catalyzed by the enzymes DGAT1 and DGAT2. According to Taha et al. (2013), magnesium can influence this process in two steps, as follows: on PAP1 $\left(\mathrm{Mg}^{2+}\right.$-dependent), because this enzyme requires $\mathrm{Mg}^{2+}$ as a cofactor for

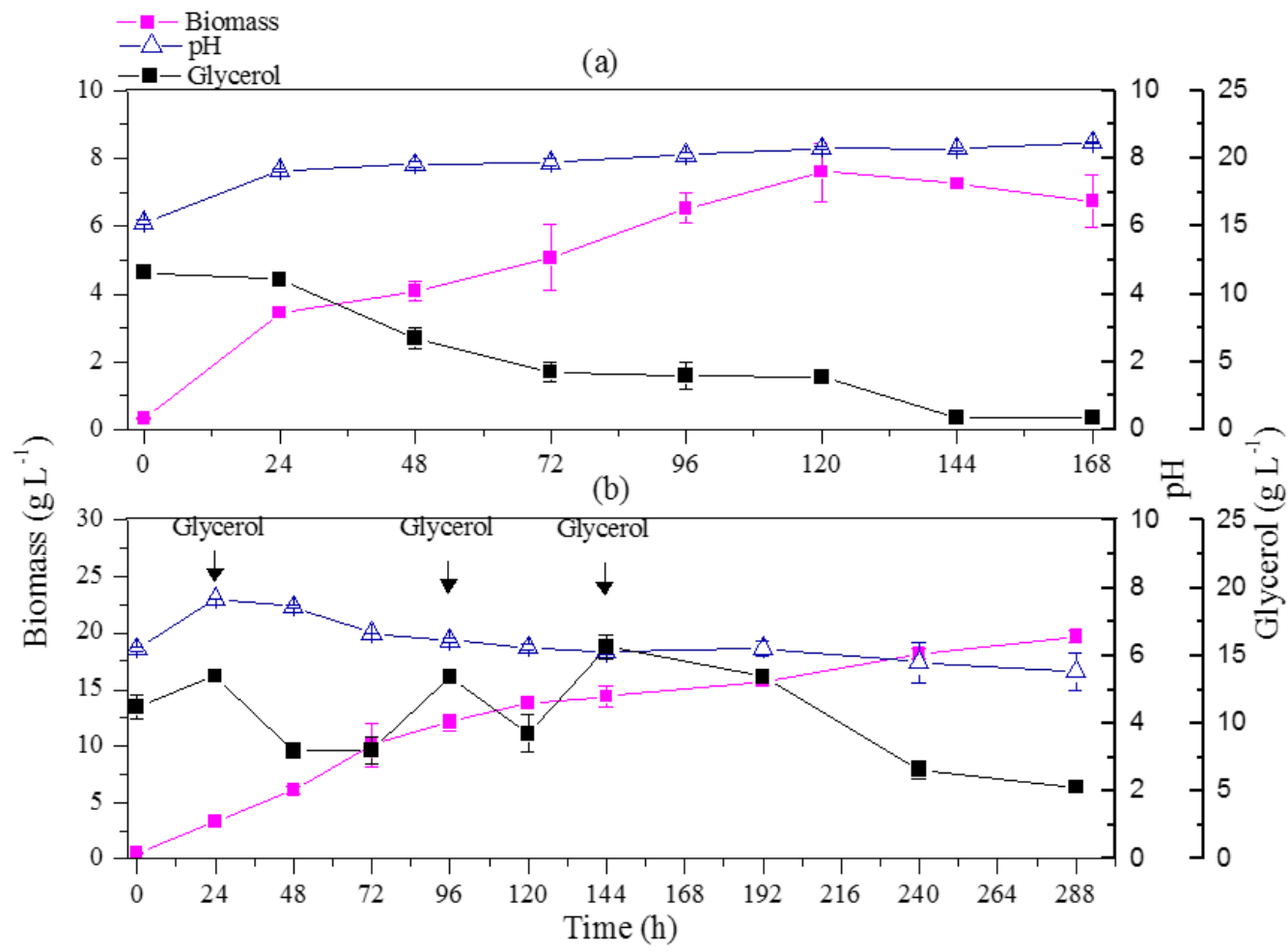

YMG5: $20 \mathrm{~mL}$ crude glycerol within $24 \mathrm{~h}, 20 \mathrm{~mL}$ within $96 \mathrm{~h}$, and $20 \mathrm{~mL}$ within $144 \mathrm{~h}$, with the addition of $3 \mathrm{~g} \mathrm{~L}^{-1} \mathrm{MgSO}_{4} \cdot 7 \mathrm{H}_{2} \mathrm{O}$ to the initial medium.

Figure 2. Kinetic profile of batch and stepwise fed-batch cultivations. (a) batch; (b) YMG5 stepwise fed-batch strategy. 
the catalytic activity, resulting in greater activity and, consequently, greater conversion to DAG; and on the enzymes DAGT1 and DAGT2, which may have their catalytic activities favored by the concentration of available magnesium, resulting in a greater conversion to TAG (Yen et al., 2008).

Similar behavior was observed by other authors with other microorganisms. Singh et al. (2016) studied the behavior of the microalga Aurantiochytrium sp. in the presence of magnesium in the culture medium $\left(5 \mathrm{~g} \mathrm{~L}^{-1}\right)$, and observed an increase in lipid content of approximately $17 \% \mathrm{CDW}$ compared with the magnesium-free cultivation. With regard to the yeast Trichosporon cutaneum, a higher lipid accumulation and biomass concentration were observed with the addition of $0.3 \mathrm{~g} \mathrm{~L}^{-1}$ of magnesium sulfate to the culture medium containing corncob hydrolysate (Chen et al., 2013). For Lipomyces starkeyi, an increase in lipid content from $41.6 \% \mathrm{CDW}$ to $56.1 \% \mathrm{CDW}$ was observed compared with the addition of 0.5 and $1.0 \mathrm{~g} \mathrm{~L}^{-1}$ of $\mathrm{MgSO}_{4} .7 \mathrm{H}_{2} \mathrm{O}$ to the culture medium (Zhao et al. 2008). Thus, it can be stated that the addition of magnesium to the culture medium stimulates lipid production by the microorganism.

\section{Fatty acid profile}

As shown in Table 4, linoleic acid was the main fatty acid found in the oil produced by $R$. mucilaginosa CCT 7688. It is common in corn, sunflower, and soybean oil, which are important vegetable oils used in biodiesel production (Ma and Hanna, 1999).

Kot et al. (2017) studied the yeast Rhodotorula glutinis CCT 7688 cultivated in a culture medium containing glycerol with $\mathrm{pH}$ between 4 and 7 , and found an increase in the synthesis of linoleic acid in detriment of the oleic acid, which is also found in microbial oils, probably due to an increase in the activity of the enzymes that convert oleic acid to linoleic acid. Liang et al. (2010) studied Cryptococcus curvatus ATCC 20509 using crude glycerol as a substrate, and

Table 4. Fatty acids profile of the biomass obtained with the YMG5 stepwise fed-batch strategy.

\begin{tabular}{|c|c|}
\hline Fatty acid & $\begin{array}{c}\text { Distribution } \\
\text { of fatty acids }(\% \mathrm{w} / \mathrm{w})\end{array}$ \\
\hline Myristoleic (C14:1) & 0.4 \\
\hline Palmitic (C16:0) & 1.4 \\
\hline Palmitoleic (C16:1) & 13.5 \\
\hline Oleic $(\mathrm{C} 18: \ln 9 \mathrm{c})$ & 3.4 \\
\hline Linoleic (C18:2n6c) & 76.8 \\
\hline$\gamma$-Linolenic (C18:3n6) & 0.4 \\
\hline$\alpha$-Linolenic (C18:3n3) & 1.7 \\
\hline Eicosatrienoic (C20:3n3) & 0.5 \\
\hline Arachidonic (C20:4n6) & 0.4 \\
\hline Tricosanoic $(\mathrm{C} 23: 0)$ & 0.5 \\
\hline Nervonic $(\mathrm{C} 24: \ln 9)$ & 0.6 \\
\hline Elaidic (C18: $\ln 9 \mathrm{t})$ & 0.2 \\
\hline
\end{tabular}

found oleic (39.6\%), palmitic (23\%), stearic (16.7\%) and linoleic $(15.2 \%)$ acids as the major fatty acids, while Duarte et al. (2013) found linoleic (54.9\%), oleic $(25.5 \%)$, palmitic $(9.8 \%)$, stearic $(13.5 \%)$ and palmitoleic $(0.4 \%)$ acids in the biomass from Candida sp. Even though the main fatty acids are the same, in the present study $R$. mucilaginosa CCT 7688 presented different proportions in comparison with the findings of these authors, with a higher linoleic acid content $(76.8 \%)$ and an expressive proportion of palmitoleic acid $(13.5 \%)$ that is generally found in small quantities. Furthermore, a small content of saturated fatty acids was observed, e.g., palmitic acid, in relation to the other microorganisms.

Moreover, it is important to emphasize the presence of essential fatty acids such as arachidonic, $\gamma$-linolenic, and $\alpha$-linolenic acids in the oil from $R$. mucilaginosa CCT 7688, albeit in small amounts. Humans cannot synthesize $\alpha$-linolenic acid, which is a precursor of two other important polyunsaturated fatty acids, including eicosapentaenoic acid (EPA) and docosahexaenoic acid (DHA). Therefore, it should be ingested at dietary levels (Nelson and Cox, 2013).

\section{Carotenoids}

R. mucilaginosa CCT 7688 was able to synthesize carotenoids associated with lipid accumulation. In this study, the cultivation strategy YMG5 corresponded to the best condition for lipid production, resulting in a volumetric carotenoid production of $2843.2 \mu \mathrm{g} \mathrm{L}^{-1}$, which represents around twice as many carotenoids as the batch process (Table 5). No significant differences

Table 5. Comparison of carotenoid production between the batch and stepwise fed-batch process at the end of the cultivation.

\begin{tabular}{|c|c|c|}
\hline Assay & $\begin{array}{c}\text { Volumetric carotenoids } \\
\left(\mu \mathrm{g} \mathrm{L^{-1 } )}\right.\end{array}$ & $\begin{array}{c}\text { Carotenoids productivity } \\
\left(\mu \mathrm{g} \mathrm{L} \mathrm{L}^{-1} \mathrm{~h}^{-1}\right)\end{array}$ \\
\hline Batch & $1345.1^{\mathrm{c}, \mathrm{d}} \pm 118.8$ & $8.01^{\mathrm{c}, \mathrm{d}} \pm 0.71$ \\
\hline YMG24 & $3216.9^{\mathrm{a}} \pm 525.9$ & $19.15^{\mathrm{a}} \pm 3.13$ \\
\hline YMG96 & $2427.4^{\mathrm{a}, \mathrm{b}} \pm 249.6$ & $14.45^{\mathrm{a}, \mathrm{b}} \pm 1.49$ \\
\hline YMG1 & $3141.6^{\mathrm{a}} \pm 586.3$ & $18.70^{\mathrm{a}} \pm 3.49$ \\
\hline YMG2 & $1928.6^{\mathrm{b}, \mathrm{c}} \pm 268.2$ & $8.04^{\mathrm{c}, \mathrm{d}} \pm 1.12$ \\
\hline YMG3 & $2368.2^{\mathrm{a}, \mathrm{b}} \pm 272.5$ & $9.87^{b, c} \pm 1.14$ \\
\hline YMG4 & $3087.0^{\mathrm{a}} \pm 155.4$ & $10.72^{b, c} \pm 0.54$ \\
\hline YMG5 & $2843.2^{\mathrm{a}, \mathrm{b}} \pm 282.0$ & $9.87^{b, c} \pm 0.98$ \\
\hline YMG6 & $2714.6^{\mathrm{a}, \mathrm{b}} \pm 103.8$ & $9.43^{\mathrm{b}, \mathrm{c}, \mathrm{d}} \pm 0.36$ \\
\hline
\end{tabular}

Mean values \pm standard deviation, $\mathrm{n}=3$.

Different letters in the same column indicate a significant difference at $95 \%$ confidence level $(\mathrm{p}<0.05)$.

YMG24: $20 \mathrm{~mL}$ crude glycerol within $24 \mathrm{~h}$; YMG96: $20 \mathrm{~mL}$ crude glycerol within $96 \mathrm{~h}$; YMG1: $20 \mathrm{~mL}$ crude glycerol within $24 \mathrm{~h}$, and $20 \mathrm{~mL}$ within 96 h; YMG2: $20 \mathrm{~mL}$ crude glycerol within 24 h, $20 \mathrm{~mL}$ within 96 h, and 20 $\mathrm{mL}$ within $144 \mathrm{~h}$. YMG3: $20 \mathrm{~mL}$ crude glycerol within $24 \mathrm{~h}, 20 \mathrm{~mL}$ within $72 \mathrm{~h}$, and $20 \mathrm{~mL}$ within $120 \mathrm{~h}$; YMG4: $20 \mathrm{~mL}$ crude glycerol within $24 \mathrm{~h}$, $20 \mathrm{~mL}$ within $96 \mathrm{~h}$, and $20 \mathrm{~mL}$ within $144 \mathrm{~h}$, with initial $\mathrm{pH}$ adjustment at 4.5; YMG5: $20 \mathrm{~mL}$ crude glycerol within $24 \mathrm{~h}, 20 \mathrm{~mL}$ within $96 \mathrm{~h}$, and 20 $\mathrm{mL}$ within $144 \mathrm{~h}$, with the addition of $3 \mathrm{~g} \mathrm{~L}^{-1} \mathrm{MgSO}_{4} .7 \mathrm{H}_{2} \mathrm{O}$ to the initial medium; YMG6: $20 \mathrm{~mL}$ crude glycerol within $24 \mathrm{~h}, 20 \mathrm{~mL}$ within $96 \mathrm{~h}$, and $20 \mathrm{~mL}$ within $144 \mathrm{~h}$, with $\mathrm{pH}$ adjustment at 4.5, and the addition of $3 \mathrm{~g} \mathrm{~L}^{-1}$ $\mathrm{MgSO}_{4} \cdot 7 \mathrm{H}_{2} \mathrm{O}$ to the initial medium. 
were observed among the other strategies, except for YMG2. However, carotenoid productivity was $9.87 \mu \mathrm{g} \mathrm{L}^{-1} \mathrm{~h}^{-1}$, which is lower than that observed for YMG24 and YMG1.

Saenge et al. (2011) produced both lipid and carotenoids from the yeast Rhodotorula glutinis, using crude glycerol as a substrate. This resulted in an increase of only $5 \%$ of total carotenoids when passing from batch cultivation to the stepwise fedbatch process, while the lipid content increased approximately $40 \%$. This result may be due to the concurrent production of carotenoids and lipids, since they can compete with each other, as both production pathways require Acetyl Co-A as a common precursor (Schneider et al., 2013). However, in the present study, YMG5 resulted in an approximately $111 \%$ increase in carotenoid production, concomitant with the increase in lipid accumulation, compared with the batch mode.

The present results are consistent with those found by other authors. Kot et al. (2017) studied the concomitant production of carotenoids and lipids in a batch process, with values of $3500 \mu \mathrm{g} \mathrm{L}^{-1}$ and $2.2 \mathrm{~g}$ $\mathrm{L}^{-1}$ of total carotenoids and lipids, respectively, for Rhodotorula glutinis cultivated in a culture medium containing glycerol and potato wastewater.

On the other hand, the addition of magnesium and adjustment of the $\mathrm{pH}$ of the medium did not lead to an increase in the synthesized carotenoids, contrary to the results obtained by other authors. Cheng and Yang (2016) evaluated carotenoid productivity by $R$. mucilaginosa in a batch process and reported a 21.4 $\%$ increase in the amount of volumetric carotenoids (3082.4 $\left.\mu \mathrm{g} \mathrm{L}^{-1}\right)$ with the addition of magnesium.

Therefore, the simultaneous lipid and carotenoid production may be an attractive alternative, with the possibility of synthesizing two bioproducts of commercial interest in the same cultivation, thus adding value to the process.

\section{CONCLUSIONS}

This study demonstrated that the stepwise fedbatch cultivation of $R$. mucilaginosa CCT 7688, as well as the addition of magnesium and the adjustment of initial $\mathrm{pH}$, led to expressive increments in total lipid production (19-fold increase), lipid content (6fold increase) and carotenoid content (2-fold increase) compared with the batch cultivation. This innovative cultivation strategy constitutes a potential technique to contribute to the economic viability of microbial oils in comparison with vegetable oils, with the simultaneous production of high added value carotenoids.

\section{ACKNOWLEDGMENTS}

This study was financed in part by the Coordenação de Aperfeiçoamento de Pessoal de Nível Superior -
Brasil (CAPES) - Finance Code 001 and the Conselho Nacional de Desenvolvimento Científico e Tecnológico (CNPq).

\section{REFERENCES}

Ageitos, J.M., Vallejo, J.A., Veiga-Crespo, P., Villa, T.G. Oil yeasts as oleaginous cell factories. Applied Microbiology and Biotechnology, 90, 1219-1227 (2011). https://doi.org/10.1007/s00253-011-3200-z

AOAC, Official Methods of Analysis. Association of Official Analytical Chemists, Washington, D.C., 17 th ed (2000).

AOCS. Official methods and recommended practices of the American Oil Chemists' Society. American Oil Chemists' Society, Champaign (2004).

Angerbauer, C., Siebenhofer, M., Mittelbach, M., Guebitz, G.M. Conversion of sewage sludge into lipids by Lipomyces starkeyi for biodiesel production. Bioresource Technology, 99, 3051-3056 (2008). https://doi.org/10.1016/j.biortech.2007.06.045

Anschau, A., Xavier, M.C.A., Hernalsteens, S., Franco, T.T. Effect of feeding strategies on lipid production by Lipomyces starkeyi. Bioresource Technology, 157, 214-222 (2014). https://doi.org/10.1016/j. biortech.2014.01.104

Béligon, V., Poughon, L., Christophe, G., Lebert, A., Larroche, C., Fontanille, P. Improvement and modelling of culture parameters to enhance biomass and lipid production by the oleaginous yeast Cryptococcus curvatus grown on acetate. Bioresource Technology, 192, 582-591 (2015). https://doi.org/10.1016/j.biortech.2015.06.041

Beopoulos, A., Cescut, J., Haddouche, R., Uribelarrea, J., Molina-Jouve, C., Nicaud, J. Yarrowia lipolytica as a model for bio-oil production. Progress in Lipid Research, 91, 692-696 (2009). https://doi. org/10.1016/j.plipres.2009.08.005

Bligh, E.G., Dyer, J.W. A rapid method of total lipid extraction and purification. Canadian Journal of Biochemistry and Physiology, 37, 911-917 (1959). https://doi.org/10.1139/y59-099

Bondioli, P., Bella, L.D. An alternative spectrophotometric method for the determination of free glycerol in biodiesel. European Journal of Lipid Science and Technology, 107, 153-157 (2005). https://doi.org/10.1002/ejlt.200401054

Cescut, J., Fillaudeau, L., Jouve, C.M., Uribelarrea, J.L. Carbon accumulation in Rhodotorula glutinis induced by nitrogen limitation. Biotechnology for Biofuels, 7, 164-175 (2014). https://doi. org/10.1186/s13068-014-0164-0

Chang, Y., Chang, K., Hsu, C., Chuang, L., Chen, C., Huang, F., Jang, H. A comparative study on batch and fed-batch cultures of oleaginous yeast Cryptococcus sp. in glucose-based media 
and corncob hydrolysate for microbial oil production. Fuel, 105, 711-717 (2013). https://doi. org/10.1016/j.fuel.2012.10.033

Chen, X.F., Huang, C., Yang, X.Y., Xiong, L., Chen, X.D., Ma, L.L. Evaluating the effect of medium composition and fermentation condition on the microbial oil production by Trichosporon cutaneum on corncob acid hydrolysate. Bioresource Technology, 143, 18-24 (2013). https://doi. org/10.1016/j.biortech.2013.05.102

Cheng, Y.T., Yang, C.F. Using strain Rhodotorula mucilaginosa to produce carotenoids using food wastes. Journal of the Taiwan Institute of Chemical Engineers, 61, 270-275 (2016). https://doi. org/10.1016/j.jtice.2015.12.027

Choi, M.H., Park, Y.H. Production of yeast biomass using waste Chinese cabbage. Biomass and Bioenergy, 25, 221-226 (2003). https://doi. org/10.1016/S0961-9534(02)00194-0

Cipolatti, E.P., Bulsing, B.A., Sá, C.S., Burkert, C.A.V., Furlong, E.B., Burkert, J.F.M. Carotenoids from Phaffia rhodozyma: antioxidant activity and stability of extracts. African Journal of Biotechnology, 14, 1982-1988 (2015). https://doi. org/10.5897/AJB2015.14682

Davies, B.H. Chemical biochemistry plant pigments. Academic Press, New York (1976).

Duarte, S.H., Ghiselli, G., Maugeri, F. Influence of culture conditions on lipid production by Candida sp. LEB-M3 using glycerol from biodiesel synthesis. Biocatalysis and Agricultural Biotechnology, 2, 339-343 (2013). https://doi. org/10.1016/j.bcab.2013.07.001

Fei, Q., O'Brien, M., Nelson, R., Chen, X., Lowell, A., Dowe, N. Enhanced lipid production by Rhodosporidium toruloides using different fedbatch feeding strategies with lignocellulosic hydrolysate as the sole carbon source. Biotechnology for Biofuels, 9, 130-142 (2016). https://doi.org/10.1186/s13068-016-0542-x

Fonseca, R.A.S., Rafael, R.S., Kalil, S.J., Burkert, C.A.V., Burkert, J.F.M. Different cell disruption methods for astaxanthin recovery by Phaffia rhodozyma. African Journal of Biotechnology, 10, 1165-1171 (2011).

Karatay, S.E., Dönmez, G. Improving the lipid accumulation properties of the yeast cells for biodiesel production using molasses. Bioresource Technology, 101, 7988-7990 (2010). https://doi. org/10.1016/j.biortech.2010.05.054

Koizumi, T. Biofuels and food security. Renewable and Sustainable Energy Reviews, 52, 829-841 (2015). https://doi.org/10.1016/j.rser.2015.06.041

Kot, A.M., Blazejak, S., Kurcz, A., Brys, J., Gientka, I., Bzducha-Wróbel, A., Maliszewska, M., Reczek, L. Effect of initial $\mathrm{pH}$ of medium with potato wastewater and glycerol on protein, lipid and carotenoid biosynthesis by Rhodotorula glutinis. Electronic Journal of Biotechnology, 27, 25-31 (2017). https://doi.org/10.1016/j.ejbt.2017.01.007

Koutinas, A.A., Chatzifragkou, A., Kopsahelis, N., Papanikolaou, S., Kookos, I.K. Design and technoeconomic evaluation of microbial oil production as a renewable resource for biodiesel and oleochemical production. Fuel, 116, 566-577 (2014). https://doi. org/10.1016/j.fuel.2013.08.045

Liang, Y., Cui, Y., Trushenski, J., Blackburn, J.W. Converting crude glycerol derived from yellow grease to lipids through yeast fermentation. Bioresource Technology, 101, 7581-7586 (2010). https://doi.org/10.1016/j.biortech.2010.04.061

Libkind, D., Brizzio, S., Ruffini, A., Gadanho, M., Broock, M., Sampaio, J.P. Molecular characterization of carotenogenic yeasts from aquatic environments in Patagonia, Argentina. Antonie Van Leeuwenhoek, 84, 313-322 (2003). https://doi.org/10.1023/A:1026058116545

Ma, F., Hanna, M.A., Biodiesel production: a review. Bioresource Technology, 70, 1-15 (1999). https:// doi.org/10.1016/S0960-8524(99)00025-5

Machado, W.R.C., Burkert, J.F.M. Optimization of agroindustrial medium for the production of carotenoids by wild yeast Sporidiobolus pararoseus. African Journal of Microbiology Research, 9, 209-219 (2015). https://doi. org/10.5897/AJMR2014.7096

Manirakiza, P., Covaci, A., Schepens, P. Comparative study on total lipid determination using Soxhlet, Roese-Goettlieb, Bligh \& Dyer, and modified Bligh \& Dyer extraction methods. Journal of Food Composition and Analysis, 14, 93-100 (2001). https://doi.org/10.1006/jfca.2000.0972

Massarolo, K.C., Souza, T.D., Ribeiro, A.C., Furlong, E.B., Soares, L.A.S. Influence of cultivation Rhizopus oryzae on rice bran on lipid fraction: fatty acids and phospholipids. Biocatalysis and Agricultural Biotechnology, 8, 204-208 (2016). https://doi.org/10.1016/j.bcab.2016.10.002

Metcalfe, L.D., Schmitz, A.A., Pelka, J.R. Rapid preparation of fatty acid esters from lipids for gas chromatography analysis. Analytical Chemistry, 38, 514-515 (1966). https://doi.org/10.1021/ ac60235a 044

Michelon, M., Borba, T.M., Rafael, R.S., Burkert, C.A.V., Burkert, J.F.M. Extraction of carotenoids from Phaffia rhodozyma: a comparison between different techniques of cell disruption. Food Science and Biotechnology, 21, 1-8 (2012). https:// doi.org/10.1007/s10068-012-0001-9

Moliné, M., Libkind, D., Broock, M.V. Production of torularhodin, torulene, and $\beta$-carotene by Rhodotorula yeasts. Methods in Molecular Biology, 898, 275-283 (2012). https://doi.org/10.1007/9781-61779-918-1_19 
Nelson, D.L., Cox, M.M. Principles of biochemistry $\left(6^{\text {th }}\right.$ ed.). W.H. Freeman and Company, New York (2013).

Official monographs USP XXI. The United States pharmacopeia. 21th revision. Official from January 1,1985

Pirozzi, D., Travaglini, G., Sagnelli, D., Sannino, F., Toscano, G. Study of a discontinuous fed-batch fermentor for the exploitation of agricultural biomasses to produce II-generation biodiesel. Chemical Engineering Transactions, 38, 169-174 (2014).

Quispe, C.A.G, Coronado, J.R., Carvalho Jr., J.A. Glycerol: production, consumption, prices, characterization and new trends in combustion. Renewable and Sustainable Energy Reviews, 27, 475-493 (2013). https://doi.org/10.1016/j. rser.2013.06.017

Raimondi, S., Rossi, M., Leonardi, A., Bianchi, M.M., Rinaldi, T., Amaretti, A. Getting lipids from glycerol: new perspectives on biotechnological exploitation of Candida freyschussii. Microbial Cell Factories, 13, 83-94 (2014). https://doi. org/10.1186/1475-2859-13-83

Rakicka, M., Lazar, Z., Dulermo, T., Fickers, P., Nicaud, J.M. Lipid production by the oleaginous yeast Yarrowia lipolytica using industrial byproducts under different culture conditions. Biotechnology for Biofuels, 8, 104-114 (2015). https://doi.org/10.1186/s13068-015-0286-Z

Saenge, C., Cheirsilp, B., Suksaroge, T.T., Bourtoom, T. Potential use of oleaginous red yeast Rhodotorula glutinis for the bioconversion of crude glycerol from biodiesel plant to lipids and carotenoids. Process Biochemistry, 46, 210-218 (2011). https:// doi.org/10.1016/j.procbio.2010.08.009

Schneider, T., Graeff-Hönninger, S., French, W.T., Hernandez, R., Merkt, N., Claupein, W., Hetrick, M., Pham, P. Lipid and carotenoid production by oleaginous red yeast Rhodotorula glutinis cultivated on brewery effluents. Energy, 61, 34-43 (2013). https://doi.org/10.1016/j.energy.2012.12.026

Shuler, M.L., Kargi, F. Bioprocess engineering $\left(2^{\text {nd }}\right.$ ed.). Prentice Hall PTR, New York (2012).

Silva, G.P., Mack, M., Contiero, J. Glycerol: a promising and abundant carbon source for industrial microbiology. Biotechnology Advances, 27, 30-39 (2009). https://doi.org/10.1016/j. biotechadv.2008.07.006

Singh, D., Barrow, C.J., Puri, M., Tuli, D.K., Mathur, A.S. Combination of calcium and magnesium ions prevents substrate inhibition and promotes biomass and lipid production in thraustochytrids under higher glycerol concentration. Algal Research, 15, 202-209 (2016). https://doi.org/10.1016/j. algal.2016.02.024

Spier, F., Buffon, J.G., Burkert, C.A.V. Bioconversion of raw glycerol generated from the synthesis of biodiesel by different oleaginous yeasts: lipid content and fatty acid profile of biomass. Indian Journal of Microbiology, 55, 415-422 (2015). https://doi.org/10.1007/s12088-015-0533-9

Taha, A.I.B.H.M., Kimoto, T., Kanada, T., Okuyama, H. Growth optimization of thraustochytrid strain 12B for the commercial production of docosahexaenoic acid. Food Science and Biotechnology, 22, 53-58 (2013). https://doi.org/10.1007/s10068-013-00482

Tchakouteu, S.S., Kopsahelis, N., Chatzifragkou, A., Kalantzi, O., Stoforos, N.G., Koutinas, A.A., Aggelis, G., Papanikolaou, S. Rhodosporidium toruloides cultivated in NaCl-enriched glucosebased media: adaptation dynamics and lipid production. Engineering in Life Sciences, 17, 237-248 (2017). https://doi.org/10.1002/ elsc. 201500125

Thiru, M., Sankh, S., Rangaswamy, V. Process for biodiesel production from Cryptococcus curvatus. Bioresource Technology, 102, 10436-10440 (2011). https://doi.org/10.1016/j.biortech.2011.08.102

UFOP - Union zur Förderung von Oel - und Proteinpflanzen E. V., UFOP report on global market supply 2017/2018. https://www.ufop.de/ files/3515/1515/2657/UFOP Report on Global Market_Supply_2017-2018.pdf. (accessed 19 June 2019).

Valduga, E., Tatsch, P.O., Tiggemann, L., Treichel, H., Toniazzo, G., Zeni, J., Di Luccio, M., Furigo, A. Produção de carotenoides: microrganismos como fonte de pigmentos naturais. Química Nova, 32, 2429-2436 (2009). https://doi.org/10.1590/S010040422009000900036

Yen, C.L.E., Stone, S.J., Koliwad, S., Harris, C., Farese, R.V. DGAT enzymes and triacylglycerol biosynthesis. Journal of Lipid Research, 49, 22832301 (2008). https://doi.org/10.1194/jlr.R800018JLR200

Zhao, X., Kong, X., Hua, Y., Feng, B., Zhao, Z.K. Medium optimization for lipid production through co-fermentation of glucose and xylose by the oleaginous yeast Lipomyces starkeyi. European Journal of Lipid Science and Technology, 110, 405-412 (2008). https://doi.org/10.1002/ ejlt.200700224 